\title{
The Examination of Sulphur Auxotrophs: A Warning
}

\author{
By J. R. POSTGATE \\ Microbiological Research Establishment, Porton, Salisbury, Wiltshire, England
}

(Received 28 June 1962)

SUMMARY

The chemical instability and reactivity of certain biologically important sulphur derivatives are recalled and their relevance to the study of sulphur auxotrophs is pointed out.

In the early stages of the biological utilization of inorganic sulphur sources the compounds involved are often relatively unstable. In the conditions used for the examination of their specific biological effects the compounds themselves, even when initially pure, may undergo chemical change by reaction with other compounds in growth media or the oxygen of the air, for example. Many inorganic sulphur compounds, particularly those which involve intermediate oxidation states of the sulphur, are unstable (see for example, Pollard \& Jones, 1958) and exchange reactions readily occur between these compounds and organic-SH or-SS-compounds. Such hazards are familiar to many workers in the field of microbial sulphur metabolism (e.g. Vishniac \& Santer ,1957; Szczepkowski, 1958). Deductions about metabolic pathways which involve such sulphur compounds and are based on growth and metabolic experiments, particularly those of long duration, should be made circumspectly. Experiments of this kind should include controls to assess the stability of the compounds in the test conditions used. Some publications concerned with the metabolism of microbial mutants which require sulphur compounds (parathiotrophs) have not explicitly described such controls. A short remainder of some of the experimental hazards involved in studying the biological activity of sulphur compounds may not be unhelpful.

Sulphite. Analytical grade sodium sulphite contains sulphate which may reach as much as 75 mole \% in old opened bottles (Postgate, 1952). Solutions aerated at physiological $\mathrm{pH}$ values oxidize spontaneously to sulphate; for example, a $0 \cdot 1 \mathrm{~m}$ solution of sodium sulphite $\left(\mathrm{Na}_{2} \mathrm{SO}_{3}\right)$ in physiological saline buffered with phosphate fell to $0.07 \mathrm{M}$ after shaking in air for $1 \mathrm{hr}$. at $37^{\circ}$ and to $0.022 \mathrm{M}$ after $2 \frac{1}{2} \mathrm{hr}$. The autoxidation of sulphite is catalysed by metals including some $(\mathrm{Cu}, \mathrm{Zn})$ that are normal 'trace' constituents of microbial media. Copper is known to be catalytically active at $10^{-9} \mathrm{~g}$./1. (Travers, 1931); its effect is antagonized by certain anti-oxidants, some of which (e.g. sucrose) may be present in microbial media.

Metabisulphite. Salts of the ion $\mathrm{S}_{2} \mathrm{O}_{5}^{\prime \prime}$ exist in the solid state and in strong solutions (Golding, 1960) but become indistinguishable from sulphites in solution because of hydrolysis of the ion to sulphite and bisulphite. Buffered to neutral pH values, metabisulphite yields the same ionic species as does sulphite. Commercial metabisulphite preparations usually contain sulphate, though in smaller proportions than sodium sulphite preparations. 
Thiosulphate. This ion is reasonably stable around $\mathrm{pH} 7$. Below $\mathrm{pH} 5$ it hydrolyses in a complex manner to yield sulphite, free sulphur dioxide and pentathionate; sulphur and $\mathrm{H}_{2} \mathrm{~S}$ may be present among its acid hydrolysis products (Pollard \& Jones, 1958); in aerated alkaline conditions it oxidizes to sulphate. At neutral $\mathrm{pH}$ values thiosulphate reacts with thiol groups (such as will be present in many biological extracts and microbial inocula) to yield free $\mathrm{H}_{2} \mathrm{~S}$, organic S-sulphonic acids (e.g. cysteine-S-sulphonate $+\mathrm{H}_{2} \mathrm{~S}$ is formed from thiosulphite and cysteine) and possibly polythio-homologues of these (Szczepkowski, 1958).

Tetrathionate. This undergoes reactions like thiosulphate with thiol groups, yielding sulphite in place of $\mathrm{H}_{2} \mathrm{~S}$.

Dithionite ('hydrosulphite'). The dithionite ion $\mathrm{S}_{2} \mathrm{O}_{4}^{\prime \prime}$ is extremely unstable in solution; in air, autoxidation to sulphite takes place rapidly (at $\mathrm{pH} 7$ a $0.1 \mathrm{M}$ solution of commercial sodium dithionite was free from this ion after $10 \mathrm{~min}$. shaking in air at room temperature). Even in the absence of oxygen dithionite solutions are unstable and hydrolyse to a mixture of thiosulphate, sulphite and free sulphur. Sodium dithionite is only stable in the anhydrous form; commercial preparations rarely claim to be pure.

Sulphoxylate. The ion $\mathrm{SO}_{2}^{\prime \prime}$ exists out of solution only as the cobaltous salt. Sodium formaldehyde sulphoxylate is a half ester and yields no sulphoxylate ion in solution.

Sulphide. The sulphide ion at $\mathrm{pH} 7$ is largely hydrolysed to free $\mathrm{H}_{2} \mathrm{~S}$ (van Niel, 1931), which as a gas evaporates rapidly from solution. For example, when a drop of $0 \cdot 1 \mathrm{M}-\mathrm{Na}_{2} \mathrm{~S}$ solution was placed on the surface of agar buffered at $\mathrm{pH} 7 \cdot 3$, no sulphide was detectable with lead acetate at the site of the drop after $15 \mathrm{~min}$. at $37^{\circ}$ in air. Where evaporation is slow, sulphide solutions photo-oxidize to form sodium thiosulphate; trace metals catalyse formation of free sulphur. In the author's experience analytical grade $\mathrm{Na}_{2} \mathrm{~S}$, even when stored in black bottles, has always contained sulphate. Many microbes which have no specialized inorganic sulphur metabolism (e.g. yeasts, $S$ phaerotilus) oxidize sulphide to free sulphur (Skerman, Demantjev \& Skyring, 1957).

Cysteine. For completeness I recall the well-known fact that cysteine autoxidizes in air to cystine at values below $\mathrm{pH} 2$; even at refrigerator temperature $\left(4^{\circ}\right)$ slow autoxidation to cystine takes place in acid solution over a week or two; this autoxidation is catalysed by metal ions $(\mathrm{Cu}, \mathrm{Hg})$.

Cysteine-S-sulphonic acid. This substance has recently assumed importance in suggested pathways of synthesis of sulphur-containing amino acids. In solution it undergoes a hydrogen ion-dependent dissociation of the general type:

$$
2 \mathrm{RSSO}_{3} \mathrm{H} \rightleftharpoons \mathrm{RSSR}+2 \mathrm{HSO}_{3}^{\prime}
$$

(Cecil \& McPhee, 1955; Cecil \& Wake, 1962).

Cysteinesulphinic and Cysteinesulphenic acids. These compounds are subject to slow spontaneous hydrolysis (rate depending on $\mathrm{pH}$ value) to yield disulphides and inorganic sulphur-containing anions such as sulphite (see Eldjarn, 1955). Such reactions are special cases of $\mathbf{R S S R}+\mathrm{SXH} \rightleftharpoons \mathrm{RSSX}+\mathbf{R S H}$ equilibria, which proceed rapidly and spontaneously at physiological $\mathrm{pH}$ values and temperatures (Kolthoff, Stricks \& Kapoor, 1955). Eldjarn \& Pihl (1956) recorded that cysteamine and glutathione established such an equilibrium in 1.25 to $3 \mathrm{~min}$. at $\mathrm{pH} \mathbf{7 . 3}$ and $37^{\circ}$. 
Polythionates having 3, 5 or 6 sulphur atoms are difficult to obtain pure and are indifferently stable in aqueous solution. Sulphane monosulphonates (Schmidt, 1957) probably do not exist in aqueous environments.

Dithionate $\left(\mathrm{S}_{2} \mathrm{O}^{\prime \prime}\right)$, sulphate, cystine and cysteic acid are stable and may be obtained pure.

\section{DISCUSSION}

The data quoted above, except those with specific citations, were obtained from text-books of chemistry (e.g. Sidgwick, 1950). Obviously, in experiments involving the use of these compounds with biological systems exposed to air in physiological conditions of $\mathrm{pH}$ value and temperature, rigorous controls are needed to evaluate their stability, and consequently the significance of any biological effects observed. Such controls have not always been mentioned in published work. For example, Clowes (1958) incubated sulphide, sulphite, cysteine or dithionite in air at $37^{\circ}$ in media in Petri dishes, used substances which contained sulphate as impurity (sulphite, dithionite) for competition experiments involving labelled sulphate, and distinguished results with metabisulphite from sulphite in a buffered system. Nakamura (1962) incubated sulphite, thiosulphate, sulphide, cysteine or cysteineS-sulphonic acid aerobically for 8 days with spores of Aspergillus nidulans in physiological conditions. Hockenhull (1949) accepted sodium formaldehyde sulphoxylate as a source of sulphoxylate; Shepherd (1958) examined some highly autoxidizable sulphur derivatives by a procedure involving incubation in air for $48 \mathrm{hr}$. at $37^{\circ}$ with media in Petri plates. It would be invidious to discuss the relevance of these criticisms to the scientific value of the papers cited since in some cases the authors may have been so well aware of the hazards mentioned that they felt it unnecessary to mention that they included appropriate controls.

The purpose of this note is to remind workers in the field of sulphur auxotrophy that the hazards listed above are real, and that publication of explicit controls to take care of them is necessary if experimental work on sulphur auxotrophy is to be accepted as significant.

I am grateful to Dr F. H. Pollard and Major L. H. Kent for reading and commenting on this contribution.

\section{REFERENCES}

Cecil, R. \& MCPheE, J. R. (1955). A kinetic study of the reactions of some disulphides with sodium sulphite. Biochem. J. 60, 496.

CECIL, R. \& WAKE, R. G. (1962). The reactions of inter- and intra-chain disulphide bonds in proteins with sulphite. Biochem. $J .82,401$.

Clowes, R. C. (1958). Nutritional studies of cysteineless mutants of Salmonella typhimurium. J. gen. Microbiol. 18, 140.

Eldjarn, L. (1955). Colloque sur la biochimie du soufre, p. 97. Paris: C.N.R.S.

Eldjarn, L. \& Pinl, A. (1956). Studies on the formation of mixed disulphides of biological importance. Acta chem. scand. 10, 1054.

GoldING, R. M. (1960). Ultraviolet absorption studies of the bisulphite-pyrosulphite equilibrium. J. Chem. Soc. p. 3711.

Hockenhule, D. J. D. (1949). The sulphur metabolism of mould fungi; the use of 'biochemical mutant' strains of Aspergillus nidulans in elucidating the biosynthesis of cystine. Biochem. biophys. Acta, 3, 326.

Kolthoff, I. M., Stricks, W. \& KAPOoR, R. C. (1955). Equilibrium constants of exchange reactions of cysteine with glutathione and with thioglycolic acid both in the oxidized and reduced state. J. Amer. chem. Soc. 77, 4733. 
Nakamura, T. (1962). Biochemical genetical studies on the pathway of sulphate assimilation in Aspergillus nidulans. J. gen. Microbiol. 27, 221.

vaN NIEL, C. B. (1931). On the morphology and physiology of the purple and green sulphur bacteria. Arch. Mikrobiol. 3, 1.

Pollard, F. H. \& Jones, D. J. (1958). The inter-relations of the sulphur oxy-acids. Symp. chem. Soc. 12, 363.

Postgate, J. R. (1952). Competitive and non-competitive inhibitors of bacterial sulphate reduction. J. gen. Microbiol. 6, 128.

Schmidt, M. (1957). Uber Säuren des Schwefels II. Zur kenntnis einer neuen Klasse von Schwefelsäuren. Z. anorg. Chem. 289, 158.

Shepherd, C. J. (1956). Pathways of cysteine synthesis in Aspergillus nidulans. J. gen. Microbiol. 15, 29.

Sidgwick, N. V. (1950). The Chemical Elements and their Compounds. Oxford: O.U.P.

Skerman, V. B. D., Demantuev, G. \& Skyring, G. W. (1957). Deposition of sulphur from hydrogen sulphide by bacteria and yeast. Nature, Lond. 179, 742.

SzczepkowskI, T. Z. (1958). Reactions of thiosulphate with cysteine. Nature, Lond. 182, 934.

Travers, A. (1931). Lecons de chimie. II. Métalloides, p. 80. Paris: Vuibert.

Vishniac, W. \& Santer, M. (1957). The thiobacilli. Bact. Rev. 21, 195. 